\title{
Cargoes of Colonial Ships
}

Two collections of the Lord shipping records preserved in Maine since the colonial era have been presented to Harvard University and the Business Historical Society by Miss Mary Patterson Lord and Charles $\mathrm{H}$. Taylor. Although considerable material on shipping is now contained in Baker Library, many invaluable manuscripts are still in private possession scattered along the Atlantic Coast. It is hoped that the extent and location of these documents will be made known for research in early American water transportation.

The older records indicate that Nathan Lord of Kennebunkport, Maine, was shipping in the late eighteenth century Madeira wine to the "London Market" at $£_{3}$ per pipe and to the "New York Market" at $£_{27}$. It is evident that Lord was at one time a sea captain for there is a document of 1790 listing Nathan Lord as master on the Brigantine Betsy leaving for Tobago Island in the West Indies at a salary of $£_{3}$ per month. He returned with a load of rum consigned to "Jonathan Hamilton Esq. of Berwick, Maine."

In 1799 Captain Lord leaves Portsmouth for Demerara (now called Georgetown), a seacoast town of British Guiana, South America, with a cargo of lumber. His brother John, owner of the goods, writes him on February 5, "it is my wishes that you proceed from hence to Demerara \& sell your Cargo for the most that it will fetch, presuming that at least you will gett thirty five Dollars for your Lumber altho I Expect the Markett is at least fifty or Sixty Dollars - \& if you sell them, I wish If Coffee, Cotton \& Sugar Can be obtained, that you will take that in return, and if that cannot be obtained to afford some Profit I shall then Recommend Bills if they are good but Rum must be low there to even make a saving - but if after you gett to Demerara you cannot find the Marketts so good as the above Calculation taking the whole of the Cargo in mind you will proceed then to such other port as you think will be for the Interest of the Voyage, you will break no Acts of Trade, that you may be under the care and Protection of divine Providence - is the sincere desire of your friend - \& wishing you health and Prosperity."

An unusual item in the collection is a statement of a cargo shipped in I 800 to the Tobago Island of " 105000 feet board \& plank, Including I5 M Joints and $2 \mathrm{M}$ feet boards for the Capt. 


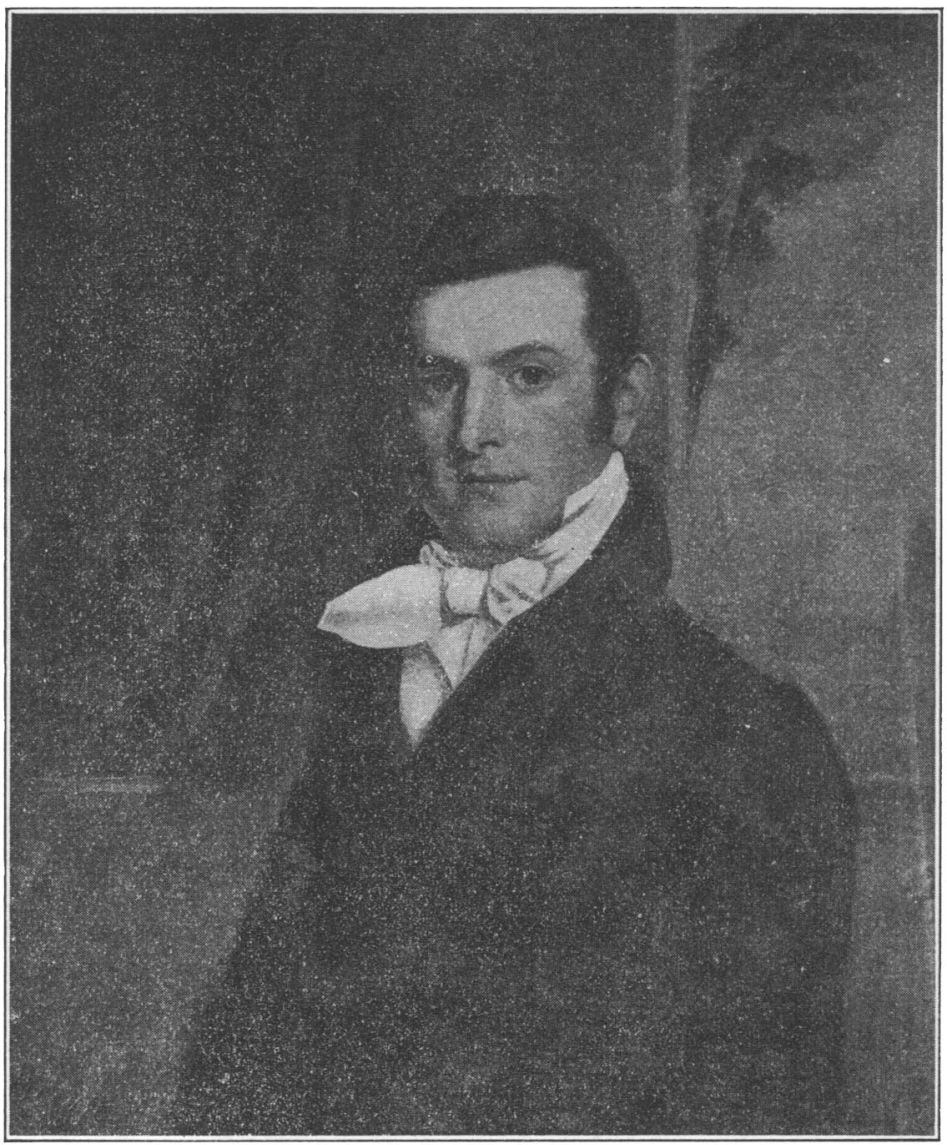

Portrait of Daniel Walker Lord now in possession of Society of Mayflower Descendants, Boston

(Artist unknown) 
adventure" as well as red oak, "good Shingles," and scale fish valued at $\$ 3166.30$ in American dollars. The prevailing custom in this period was, of course, to reckon in terms of English pounds and shillings.

The second group of papers presented to Harvard University by Miss Lord is a part of the voluminous records of Daniel Walker Lord, son of Nathan Lord, who directly carried on the merchandising business in Kennebunkport from I820 to the post-Civil War period. By 1830 the business had expanded considerably and had changed in character. The emphasis lay largely on the threecornered trade with the West Indies and the western coast of Europe.

The most complete set of documents center around the Brig Union which made numerous trans-Atlantic "flights" until it sank off the coast of Cuba in I 83I. The first voyage of the brig for which we have records was in 1824. Captain Oliver Smith arrived in Kingston, Jamaica, on November 9, I824, and writes on November I 8 to Daniel Lord, "There is no freight to be had at this place and I think I shall have to go for a load of wood." Then evidently with his own cargo in mind, "The last sale of W. T. lumber was a small cargo from Bath at $24 \$$. The next will probably be lower, seven vessels having arrived in the last 24 hours, from British America with Fish and lumber. P. pine lumber is worth $36 \$$, Southern R. O. staves by the cargo still at $40 \$$, cypress shingles I $2 \$$ four at $7 \frac{1}{4}$ No colonial produce in the market."

By Christmas he has moved up to Carmen in the State of Campeche, Mexico, and has contracted for a cargo of logwood at "fifty two cents per quintal Spanish weight. With the export duty and port charges on the vessel, it will stand on about $14 \frac{1}{4} \$$ per ton English."

An account sheet for Joseph Osborn, Lord's agent in New York, indicates the division of the purchase among New England merchants. Samuel Hicks secured Ioo tons of logwood at \$26; A. O. Brodie, I 5 tons, \$27; S. N. Stilwell, Io tons, \$27; George Bingley, I0o tons, \$26; G. G. \& S. Howland, 8 tons, \$27; and Daniel Lord, 17 tons at $\$ 26$. Full confidence was placed in the captain who sailed for France with the cargo to dispose of it as profitably as possible for these merchants.

From Havre, Smith writes on May 3, I825 (after commenting that he arrived on May $\mathrm{I}$ after a rough passage) that "the wood is not Sold, it is worth about forty dolls. per ton, clear of duty." A 


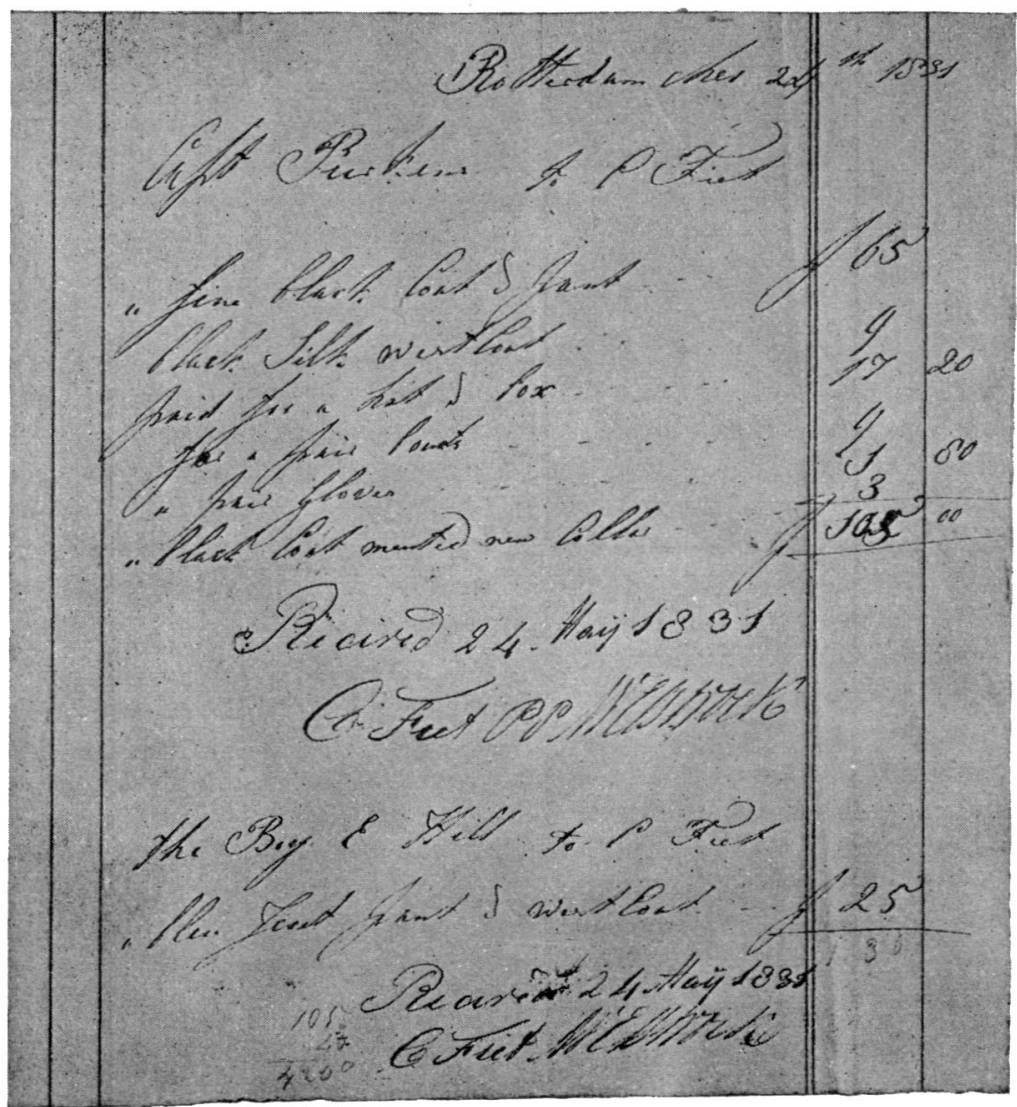

Captain Perkins' Extravagances in a Foreign Port 
few days later he states, "Since I wrote you I have agreed to land at Rochell with Brandy for N. York at eight dollars per ton of two hundred and forty galls. to be landed in fifteen days." He informs Lord that he has asked their French brokers to secure salt to the value of $\$ 1000$ but that since then he has decided he does not want it and unless they have actually purchased and insist upon his taking the salt, he will sail without it. All the logwood was sold except 24 tons which finally went at $\$ 60$ a ton. He comments, "Exchange on London 60 days, 24 francs 80 to 85 centimes per pound sterling."

The Union loaded with 56,615 gallons of brandy and "two tons of dry goods" left Rochelle for the United States - over a hundred years ago. It reached New York in 62 days and Captain Smith thinks that the greatest objection to the Brig's sailing to and from Europe is its slowness as "she ought to have made the last passage in thirty five days."

The Union made voyages regularly every year - carrying molasses to New York, cotton to Havre and Liverpool, boots and shoes to Mobile - until the catastrophic event on November 9, I83I, when the captain writes to Lord, "Unhappy to inform you I have lost the Brig Union on the fourth of this month between the Island of Cuba and Jamaica. She sank down under me." Although the crew threw the load of salt overboard, the leak increased and the captain says, "With tears I left her sinking, and the boat leaking almost as bade as the Brig, I heardly new wither to stop on board the Brig and dei, or go in to the Boats and dei" but "Providence smiled" for "after suffering hunger and heardships in the boats four nights and four days I have arrived here with all hands."

\section{American Investment Trusts}

THE groundwork for a study of American investment trusts is contained in a mass of documents presented to the Business Historical Society by Edgar Higgins, investment trust consultant of New York City. Mr. Higgins has devoted years to collecting this material, part of which has been collated under his direction, and the remainder is now undergoing classification. It covers such diverse ranges as company reports, newspaper and magazine articles, advertisements and legal forms for the type of trust with practically unlimited managerial power to that which has a minimum.

The American trust; at first slow to get a start, has developed to enormous size and variability of types since 1924 . Its present posi- 